\title{
PROGRAM STUDI PENDIDIKAN AGAMA ISLAM DALAM BERBAGAI
}

\section{SUDUT PANDANG}

\author{
Dede Setiawan \\ Prodi Pendidikan Agama Islam, Fakultas Agama Islam, Universitas Nahdlatul Ulama \\ Indonesia \\ E-mail: dewa@unusia.ac.id
}

\begin{abstract}
Article Information
Informasi Artikel

2018

Naskah direvisi:

September 2018

Naskah disetujui:

September 2018

Naskah dipublish:

Oktober 2018

Abstak

Penelitian ini mencoba menjawab integrasi ilmu keislaman dengan ilmu umum dalam progam studi Pendidikan Agama Islam. Persoalan integrasi ilmu, di lembaga pendidikan tinggi keagamaan

10 Islam belum tuntas. Hasil dari penelitian adalah secara ontologi jelas asalnya, epistimologi kuat teorinya, dan aksiologi dapat 25 diopersionalkan dalam proses kegiatan belajar mengajar $d$. Sehingga bangunan ilmu Prodi Pendidikan Agama Islam sudah kuat

17 dan kokoh. Metode penelitian menggunakan metode kualitatif; lebih fokus pada studi perpustakaan dan pengamatan serta pengalaman dalam mengelola Prodi Pendidikan Agama Islam.
\end{abstract}

\section{Kata Kunci Pendidikan, Agama Islam}

\section{PENDAHULUAN}

Kehadiran lembaga pendidikan Islam di Indonesia merupakan wujud dari kesadaran dan sikap patriotisme serta rasa nasionalisme sekaligus sebagai respon tokoh-tokoh Islam terhadap kepincangan-kepincangan di masyarakat Indonesia pada akhir abad 19 M yang mengalami kemunduran total akibat penjajahan Belanda ${ }^{1}$. Tanpa kehadiran lembaga pendidikan Islam, sebagaimana ditegaskan Drs.H. Mudjahid, M.Sc, salah seorang dosen Fakultas Tarbiyah UIN Syarif Hidayatullah Jakarta, seperti pondok pesantren dan madrasah, bahkan perguruan tinggi keagamaan Islam swasta di nusantara, agama Islam sudah lama lenyap di Indonesia ${ }^{2}$.

Perguruan Tinggi Keagamaan Islam (PTKI) baik negeri mauun swasta sebagian besar memiliki program studi Pendidikan Agama Islam atau PAI ${ }^{3}$. Dalam

\footnotetext{
1 Hasbullah, Sejarah Pendidikan Islam di Indonesia; Lintasan Sejarah Pertumbuhan dan Perkembangan. Jakarta, PT Raja Grafindo Persada, 1999 hal. 91

${ }^{2}$ Mudjahid, M,Sc, Komentar Ahli dalam Seminar Hasil Penelitian Tenmtang Pendidikan Islam Pasca Reformasi yang diselenggarakan Balai Litbang Keagamaan DKI Jakarta, di Hotel Bumi Wiyata, Depok, ${ }^{3}$ Data Kementerian Ristek Dikti, yang dilacak melalui Forlaf PDDIKTI, jumlah Prodi Pendidikan Agama Islam sebanyak 562 baik yang dieselanggarakan oleh PTKIN, PTKIS, FAI dan IKIP yang berubah menjadi universutas. Dirjen Pendidikan Islam Kementerian Agama RI memoratorium pembukaan Prodi Pendidikan Agama Islam. Prodi ini sudah jenuh dan overload, salah satu alasannya.
} 
perkembangannya, Prodi Pendidikan Agama Islam tidak hanya mengajarkan ilmu agama Islam (an sich) seperti hadits, fiqh, ushul fiqh, tafsir, dan sebagainya. Namun, juga mahasiswa Tarbiyah Prodi Pendidikan Agama Islam mempelajari teori - teori tentang psikologi yang, sebagian besar berasal dari pemikiran sarjana Barat, seperti mata kuliah Ilmu Jiwa Belajar, Bimbingan dan Konseling, Ilmu Jiwa Perkembangan, Kesehatan Mental, dan sejenisnya,

Maka akan timbul pertanyaan: Bagaimana bangunan keilmauan Prodi Pendidikan Agama Islam? Sejauhmana mana bangunan keilmuan Prodi Pendidikan Agama Islam dapat menjadi sebuah pondasi pendidikan Agama Islam. Maksud dari penelitian ini adalah untuk menjelaskan bangunan keilmuan Prodi Pendidikan Islam sebagai bagian dari perkembangan ilmu pengetahuan khususnya dalam bidang pendidikan. Tujuannya untuk digunakan dalam pengelolaan Prodi Pendidikan Agama Islam, khususnya di fakultas Tarbiyah Institut Agama Islam Jamiat Kheir dan fakultas Tarbiyah lingkungan PTKIN maupun PTKIS pada umumnya, Penelitian ini akan mengurai relevansi Prodi Pendidikan Agama Islam dikaitkan dengan reintegrasi ilmu keislaman dengan ilmu umum ${ }^{4}$. Sebagai metodeloginya menggunakan metode kualitatif $^{5}$, dan lebih banyak menggunakan studi perpusatkaan dan pengamatan bahkan pengamatan dalam praktek - praktek dalam pengelolaan Progam Studi Pendidikan Agama Islam, Untuk analisa menggunankan pendekatan deskriftif, Dengan demikian penelitian ini deskriftif - kualitatif.

\section{PENGERTIAN PENDIDIKAN AGAMA ISLAM}

Banyak ragam pengertian pendidikan agama Islam. Namun, dalam kesempatan ini, akan diambil beberapa definisi atau pengertian yang dikemukan oleh para tokoh yang konsern terhadap pendidikan agama Islam. Zarkowi Soejoeti, memberi tiga

\footnotetext{
${ }^{4}$ Permasalahan integrasi ilmu - ilmu keislaman dengan ilmu - ilmu umum sudah menjadi bahan perdebatan sejak tahun 1986. Saat itu, Ismail al Faruqi melontarkan wacana Islamisasi ilmu pengetahuan. Baca: Ismail al Faruqi: Islamisasi Ilmu Pengetahuan. (Bandung: Mizan, 1986). Setelah IAIN berubah menjadi UIN dan dibukanya fakultas umum maka persoalan ini muncul kembali. Ada dua buku yang berbicara tentang hal ini. Pertama karya Guru Besar UIN Sunan Kali Jaga Yogjakarta Prof Dr M Amin Abdullah, Islamic Studies di Perguruan Tinggi: Pendekatan Integratif - Interkonektif. Yogjakarta: Pustaka Pelajar, 2006. Kedua, karya Guru Besar UIN Syarif Hidayatullah, Prof Dr Mulyadhi Kartanegara, Integrasi Ilmu Sebuah Rekonstruksi Holistik. Bandung: Arasy Mizan, 2003.

${ }^{5}$ Lexy J Moleong, Metodelogi Penelitian Kualitatif. Bandung: PT Remaja Rosdakarya, 2006, hal. 9. Bandingkan dengan Masri Singarimbun dan Sofian Effendi, Metode Penelitian Survai. Jakarta: LP3ES, 1989, hal. 22
} 
pengertian pendidikan (agama) Islam Pertama, lembaga pendidikan itu pendirian dan penyelenggaraannya didorong oleh hasrat mengejawantahkan nilai - nilai Islam yang tercermin dalam nama lembaga pendidikan itu dan kegiatan yang diselenggarakan ${ }^{6}$. Dalam pengertian ini, Islam dilihat sebagai sumber nilai yang harus diwujudkan dalam kehidupan lembaga pendidikan yang bersangkutan.

Kedua, lembaga pendidikan yang memberikan perhatian dan menyelenggarakan kajian tentang Islam yang tercermin dalam program kajian sebagai ilmu dan diperlukan seperti ilmu - ilmu lain yang menjadi program kajian lembaga Islam yang bersangkutan. Ketiga, mengandung kedua pengertian di atas, dalam arti lembaga tersebut memperlakukan Islam sebagai sumber nilai bagi sikap dan tingkah laku yang harus tercermin dalam penyelenggaraannya maupun sebagai bidang kajian yang tercermin dalam program kajiannya ${ }^{7}$.

M. Yusuf al-Qardhawi memberikan pengertian bahwa pendidikan Islam adalah pendidikan manusia seutuhnya (akal dan hatinya, rohani dan jasmaninya, akhlak dan keterampilannya). Pendidikan Islam menyiapkan manusia untuk hidup, baik dalam keadaan damai maupun perang, dan menyiapkannya untuk menghadapi masyarakat dengan segala kebaikan dan kejahatannya, manis dan pahitnya ${ }^{8}$.

Pendidikan Islam dapat dirumuskan sebagai proses bimbingan (pimpinan, tuntutan, usulan) oleh subyek didik terhadap perkembangan jiwa (pikiran, perasaan, kemauan, intusi, dan sebagainya), dan raga obyek didik dengan bahan - bahan materi tertentu, pada jangka waktu tertentu, dengan metode tertentu dan dengan alat perlengkapan yang ada ke arah Bangunan keilmuan (body of knowledge) Prodi Pendidikan Agama Islam - harus memiliki basis keilmuan yang dapat dipertanggungjawabkan kebenaran sesuai metode ilmiah. Dengan kata lain, semua mata kuliah yang diajarkan pada jurusan tersebut mempunyai struktur kurikulum, materi, syllabus, bahan ajar dan metedologi pengajaran, termasuk juga alokasi waktu perkuliahan dan ruang belajar.

\footnotetext{
${ }^{6}$ Aumardi Azra, Pendidikan Islam: Tradisi dan Modernisasi Menuju Milenium Baru. Jakarta: Logos Wacana Ilmu, 2000, hal. 24

${ }^{7}$ A Malik Fadjar, Reoreintasi Pendidikan Islam, Jakarta: Fajar Dunia, 1999, hal. 31

${ }^{8}$ M Yusuf al - Qardhawy, Pendidikan Islam dan Madrasah Hasan Al Bana, terj. Prof. Bustami A. Gani dan Drs. Zainal Abidin Ahmad. Jakarta: Bulan Bintang, 1980, hal.157
} 


\section{BANGUNAN ILMU PRODI PENDIDIKAN AGAMA ISLAM}

Secara ontologis ${ }^{9}$, Prodi PAI tidak men- dikotomi-kan ilmu agama dan ilmu umum, profan dan sekuler, dunia dan akherat; karena semua ilmu bersumber dari Zat Yang Maha Berilmu, yang tak lain Tuhan, Allah Swt- sendiri. Jika ilmu agama bersumber pada ayat - ayat tadwini; ilmu sekuler/umum bersumber pada kauni ${ }^{10}$. Apabila yang pertama menggunakan metode bayani, burhani, dan irfani; maka yang kedua menggunakan metode induktif dan deduktif dengan cara pengamatan/ obervasi ${ }^{11}$.

Semangat Konperensi Pendidikan Islam se- Dunia di Mekkah 1977, menegaskan bahwa ilmu agama dan ilmu umum merupakan satu: Karena hakehatnya keduanya berasal dari Allah. Oleh karena itu, dalam pandangan yang dikhotomi ini kedua ilmu disatukan : ilmu yang berasal dari Allah (ilmu abadi: Ilahi) menjadi asas atau dasar ilmu yang berasal dari otak manusia (ilmu pencapaian, penalaran, intelektual: insani ${ }^{12}$.

Kesimpulan yang diambil oleh Mohammad Daud Ali tersebut merupakan elobarasi dari klasifikasi ilmu yang dibuat oleh Al Farabi $(258 \mathrm{H}-339 \mathrm{H} / 870 \mathrm{M}-950$ M), Al Gazali (450 H - 505 H/1058 M-1111 M), dan Quthubuddin al Syirazi (634 H $-710 \mathrm{H} / 1256 \mathrm{M}-1311 \mathrm{M})^{13}$.

Menurut pandangan filsuf Barat, ilmu agama, termasuk PAI, bukan bagian ilmu pengetahuan. Alasannya, sebuah ilmu (pengetahuan) harus diobservasi, dapat diverifikasi kebenarannya melalui berbagai pengujian, dan bersifat empiris. Sebagaimana pendapat David Hume, Bertrand Russell, Emmanuel Kant, karena ilmu agama (Islam) tidak empiris, tidak skeptic, tidak induktif, dan tidak deduktif ${ }^{14}$. Sementara ilmu agama (Islam), kebenarannya merupakan taken for granted (sesuatu yang sudah terjadi). Walaupun ada ilmu - ilmu agama yang bersifat interpreratif dan ijtihadi

\footnotetext{
${ }^{9}$ Dalam penelitian ini, peneliti mengambil konsep ontologis, epistomologis, dan aksiologis dari Prof Dr C.A. van Peursen, dalam buku Strategi Kebudayaan. Alih bahasa Dick Hartoko. Yogjakarta: Penerbit Kanisius, 1992

${ }^{10}$ Mulyadhi Kartanegara, Loc Cit, hal, 22

11 Jujun S Suriasumantri, Ilmu dalam Perspektif.: Sebuah Kumpulan Karangan tentang Hakehat Ilmu. Jakarta: Gramedia, 1978, hal, 43 -45 2006, hal. 393

${ }^{12}$ Mohammad Daud Ali, Pendidikan Agama Islam. Jakarta: RajaGrafindo Persada

${ }^{13}$ Osman Bakar, Hierarki Ilmu Menurut Al Farabi, Al Gazali, Quth al Din al Syirazi. Bandung: Mizan, 2006

${ }^{14}$ Untuk mendalami masalah ini buku membacara buku Bakker, Anton, Metode - Metode Filsafat. Jakarta: Ghalia Indonesia, 1982 dan buku Jujun S Suriasumatri, op cit
} 
Sebagai misal, materi perkuliahan Pendidikan Agama Islam mulai dari AlQuran, hadits, fiqh, tauhid, tafsir, akhlak, dan seterusnya tidak berubah sejak awal materi tersebut dikodifikasi, diajarkan, dikembangkan sampai sekarang. Mulai dari bersuci dengan teknologi sampai menjalankan ibadah mahdhah dari zaman Rasulullah sampai sekarang tidak mengalami perubahan. Demikian pula, materi kurikulum PAI mulai dari pelajaran fiqh, akhlak, tauhid/akidah, sejarah kebudayaan Islam pun tidak berubah. Hanya metodelogi dan strategi belajar - mengajar yang berkembang sesuai dengan tren teknologi dan perkembangan zaman.

Untuk mata kuliah tafsir, yang berubah adalah metode penafsiran ayat $\mathrm{Al}$ Qur'an. Sebagai misal, dalam ilmu tafsir, telah berkembang tafsir Al Qur'an dengan metode hermeneutik ${ }^{15}$ yang mulai digandrung kalangan Islam progresif namun metode ini belum diajarkan di bangku - bangku perkuliahan tafsir Al Qur'an pada Prodi Pendidikan Agama Islam fakultas Tarbiyah pada perguruan tinggi keagamaaan Islam swasta.

Mata kuliah tafsir yang diajarkan pada fakultas lingkup PTKIN dan PTKIS adalah metode ijmali, tahlili, muqaran, dan maudhui. Sebagaimana Quraisy Syihab menggunakan metode maudhui (tematik) dalam tafsir Membumikan Al-Quran ${ }^{16}$ dan $A l$ $M_{i s b a h^{17}}$.Sementara penafsiran Al Quran dengan metode hermeneutik dikecam habis habisan karena dianggap menyimpang dari tradisi Rasulullah SAW, para sahabat dan para ulama ahli tafsir salafus shaleh. Tafsir dengan metode hermeneutic dipengaruhi oleh pemikiran Barat yang liberal; ayat - ayat Al Quran tidak ada bedanya dengan teks - teks buku biasa ${ }^{18}$.

Prodi Pendidikan Agama Islam, selain menyebarkan kebenaran absolut tentang ilmu pengetahuan keagamaan, juga melakukan penelitian yang berkaitan dengan dunia pendidikan. Dalam penelitian ini, ingin mencari 'kebenaran' relative yang hidup dalam masyarakat Indonesia. Berpijak dari sini, maka Prodi PAI memanfaatkan berbagai teori tentang kebenaran. Dalam dunia ilmiah, teori kebenaran berangkat dari tiga hal: Pertama, teori korespondensi (pertautan dengan

\footnotetext{
${ }^{15}$ Muhammad Shahrur, Tashwirul Afkar Edisi No 16 Tahun 2004

${ }^{16}$ M Quraisy Shihab, Membumikan Al Quran. Bandung : Mizan, 1986

$17 \_$Al Misbah. Jakarta: Lentera Hati, 2014

${ }^{18}$ Adian Husaini dan Abdurrahman al Baghdadi, Hermeneutika Tafsir Al Qur'an Jakarta: Gema Insani Press, 2004, hal, 4 - 5
} 
fakta); kedua, koherensi (teori tengang koherensi); dan ketiga, pragmatis (tentang kemanfaatan $)^{19}$.

Sementara, untuk memperoleh kebenaran Ali Syariati menegaskan, bahwa penggunaan metode ilmiah tidaklah tunggal dari sekian banyak metode yang berkembang dewasa ini. Karena Islam bukan agama satu dimensi (uni dimensional). Untuk mempelajari Islam yang banyak dimensinya itu, selain dengan memanfaatkan metode filosofis, pun harus menggunakan metode - metode yang terdapat dalam ilmu manusia dewasa ini $^{20}$.

Terlepas dari perdebatan tersebut, kemudian merujuk dari pemahaman yang disampaikan Kartanegara di atas, maka mata kuliah yang diajarkan pada fakultas Tarbiyah Prodi PAI tradisi keilmuan dari pemikir Islam diintegrasikan dengan tradisi keilmuan dari pemikiran filosuf Barat. Dalam pengajaran materi kuliah Ilmu Jiwa, misalnya, selain menyajikan pemikiran - pemikiran dari ahli ilmu jiwa seperti Sigmun Freud dengan psiko analisa, yaitu ego dan aid ${ }^{21}$,serta Abraham Maslow dengan teori motivasinya ${ }^{22}$, melainkan juga mengeksplorasi pemikiran filsuf Islam seperti Al Kindi, Al Razi, Al Farabi, Ibn Sina, Al Ghazali, dan filsuf muslim lainnya, yang fasih bicara soal rohani (jiwa) manusia. Sehingga kurikulum Ilmu Jiwa Belajar, Psikologi Pendidikan, Bimbingan dan Konseling, dan sejenisnya pada PS PAI semakin kuat dan kukuh pijakan basis epistimologi.

Sebagai perguruan tinggi tinggi agama Islam, bukan hanya bersandar sebagai nilai - nilai Ilahiyah ( tazkiyatun nufus), akan tetapi senantiasa menempatkan AlQuran dan Hadis sebagai sumber ilmu pengetahuan. Maka mata kuliah - mata kuliah yang diajarkan pada Prodi PAI harus mengeksplorasi kedua sumber tersebut. Dengan demikian, Prodi PAI bukan hanya sinergi - integrasi - koneksi meminjam istilah M Amin Abdullah atau integrasi ilmu meminjam Mulyadhi Kartanagera- antara mata

\footnotetext{
${ }^{19}$ Harold Titus dkk, Persoalan _ Persoalan Filsafat, alih bahasa M Rasjidi. Jakarta: Bulan Bintang, 1984, hal. 237 - 244

${ }^{20}$ Ali Syariati, On The Sociology of Islam. Berkeley: Mizan Press, 1979, hal. 72

${ }^{21}$ Sigmund Freud, The Ego dan The Id. New York: Norton, 1962

${ }^{22}$ Abraham Maslow H, Motivation and Personality. New York: Harper, 1945. Secara garis besar dia membagi motivasi menjadi lima fisiologi, rasa aman, afiliasi, harga diri, dan aktualisasi diri. Kemudian bandingkan dengan hadits ikhlas beramal: Innamal a'malu bin niyat...
} 
kuliah keagamaan, kemudian dicangkokkan dengan mata kuliah ilmu umum ${ }^{23}$. Melainkan, Prodi PAI merupakan penerapan ajaran nilai - nilai Islam sebagai dasar Ilmu Pengetahuan ${ }^{24}$.

Secara aksiologis, Prodi PAI harus mampu menjawab persoalan - persoalan praksis yang berkembang di masyarakat. Sehingga materi perkuliahan pada jurusan ini harus memiliki perspektif masyarakat yang majemuk (plural), multicultural, dan HAM. Prodi Pendidikan Agama Islam harus mampu memberi solusi dan pencerahan bagaimana hubungan antara materi PAI dengan, misalnya, yang diajarkan dalam sekolah - sekolah umum.

Metode - metode pengajarannya pun lebih banyak menggunakan androgogi dan emansipatoris dari pada menggunakan metode indoktrinatif dan dogmatis. Out come yang diharapkan, masyarakat Jakarta dan sekitarnyayang multi kompleks akan memiliki guru agama, ustadz, guru ngaji, atau apalah sebutannya yang memiliki kompetensi ilmu (PAI) sesuai karakter masyarakat yang pluralis dan multilkulturalis ${ }^{25}$, akan tetapi bukan dalam arti isme. Dalam konteks lebih luas, Prodi Pendidikan Agama Islam dapat mengembangkan masyarakat belajar yang kreatif, mandiri terbuka (open mindend), demokratis, inkuiri, dan efektif. Sebab kecenderungan utama masa depan adalah adanya perubahan yang cepat (increasingly rate of change) yang mengakibatkan ketidakpastian, di samping kepastian - kepastian yang didasarkan fakta sosial - budaya yang berkembang ${ }^{26}$.

\section{KESIMPULAN}

Dari kajian diatas, bahwa Prodi Pendidikan Agama Islam yang memiliki landasan yang keilmuan kukuh atau kuat, baik dilihat dari ontologis, etimologis, maupun aksiologis. Selain mengembangkan ilmu yang bersumber pada $\mathrm{Al}$ Quran dan Hadits, juga teori - teori keilmuan baik kajian ilmu pendidkan maupun kajian ilmu lainnya. Oleh karena itu, Prodi Pendidikan Agama Islam dapat menjadi

\footnotetext{
${ }^{23}$ Kecenderungan seperti ini munculnya PS Perbankan Islam, PS Perbankan Syariat, PS Akuntansi Islam dan sejenisnya. Pencangkokan ini disebabkan basis keilmuannya atau ontology dan epistimologi-nya tidak kokoh. Atau dalam kata lain PS - PS tersebut sedang mencari formula keilmuan yang pas.

${ }^{24}$ Baca QS Al Muluk /67: 26

25 Baca hasil penelitian Balai Litbang Agama Jakarta dalam bahasan ini. Akhmad Syafei, dkk. Pendidikan Agama Islam dalam Perspektif Multikulturalisme. Jakarta: Balai Litbang Agama Jakarta, 2009

${ }^{26}$ Syafrudin dan Irwan Nasution, Manajemen Pembelajaran. Jakarta: Ciputat Press, 2005, hal. 19
} 
pijakan dalam mengelola sebuah pembelajaran yang sistematis, terorganisasi, dan terukur lewat berbagai kegiatan baik penguasaan kurikulum, perancanaan pembelajaran, dan seterusnya yang, semuanya itu diajarkan oleh fakultas Tarbiyah Prodi Pendidikan Agama Islam, terangkum dalam bentuk silabus, bahan ajar, dan SAP serta dalam bentuk penelitian dan pengabdian kepada masyarakat.

\section{DAFTAR PUSTAKA}

Abdullah, M Amin, Islamic Studies di Perguruan Pendekatan Integratif-Interkonektif. Yogjakarta: Pustaka Pelajar, 2006.

Arifin, Anwar, Memahami Paradigma Baru Pendidikan Nasional dalam Undang Undang Sisdiknas. Jakarta: Ditjen Kelembagaan Agama Islam Kementerian Agama RI, 2003

Azra, Azumardi, Pendidikan Islam: Tradisi dan Modernisasi Menuju Milenium Baru. Jakarta: Logos Wacana Ilmu, 2000.

Anshari, Endang Saefuddin, Pokok - Pokok Pikiran tentang Islam. Jakarta: Usaha Interprise, 1976

Ali, Mohammad Daud, Pendidikan Agama Islam. Jakarta: RajaGrafindo Persada, 2006

Arifin, M., Filsafat Pendidikan Islam. Jakarta: Bina Aksara, 1987

Bakker, Anton, Metode - Metode Filsafat. Jakarta: Ghalia Indonesia, 1982

Bakar, Osman, Hierarki Ilmu Menurut Al Farabi, Al Gazali, Quth al Din al Syirazi. Bandung: Mizan, 2006

Buchori, Mochtar, dkk., Reorientasi Ilmu Pendidikan di Indonesia. Jakarta: IKIP Muhammadiyah Jakarta Press, 1995

Dawud, Abu, Sunan Abu Dawud. Beirut: Al Maktabah As Syamilah, tt

Fadjar, A. Malik, Reorentasi Pendidikan Islam. Jakarta: Fajar Dunia, 1999

Freud, Sigmund, The Ego and The Id. New York : Norton, 1962

Hasbullah, Sejarah Pendidikan Islam di Indonesia; Lintasan Sejarah Pertumbuhan dan perkembangan. Jakarta, PT Raja Grafindo Persada, 1999

Hidayat, Komaruddin dan Hendro Prasetyo (Ed.), Problem dan Prospek IAIN Antologi Pendidikan Tinggi Islam. Jakarta: Direktorat Pembinaan Perguruan Tinggi Agama Islam Direktorat Jenderal Pembinaan Kelembagaan Agama Islam Departemen Agama RI, 2000 
Husaini, Adian dan Abdurrahman al Baghdadi, Hermeneutika Tafsir Al Qur'an. Jakarta: Gema Insani Press, 2004

Kartanegara, Mulyadhi, Integrasi Ilmu Sebuah Rekonstruksi Holistik. Bandung: Arasy Mizan, 2003

Langgulung, Hasan, Manusia dan Pendidikan: Suatu Analisa Psikologi dan Pendidikan. Jakarta: Pustaka Al Husna, 1989

Maslow H, Abraham, Motivation and Personality. New York: Harper, 1945

Moleong, Lexy J., Metodelogi Penelitian Kualitatif. Bandung: PT Remaja Rosdakarya, 2006

Nahlawi, Abdurrahman, Prinsip - Prinsip dan Metode Pendidikan Islam. Bandung: CV Diponegoro, 1992

Noer, Deliar, Gerakan Modern Islam Indonesia 1900-1942. Jakarta: LP3ES, 1984

Nolan, Smite, dan Titus dkk, Persoalan-Persoalan Filsafat, penerjemah HM Rasjidi. Jakarta: PT Bulan Bintang, 1984

Perebutan Identitas Islam Pergulatan Islamisme dan Islam Progresif, Tashwirul Afkar Jurnal Refleksi Pemikiran Keagamaan \& Kebudayaan, Edisi No 16 Tahun 2004 Qardawy, Yusuf Al, Pendidikan Islam dan Madrasah Hasan Al Bana, terj. Prof. Bustami A. Gani dan Drs. Zainal Abidin Ahmad. Jakarta: Bulan Bintang, 1980 Sjalabi, Achmad, Sejarah Pendidikan Islam. Djakarta, PT Bulan Bintang, 1973 Shihab, Quraisy, Membumikan Al Quran. Bandung: Mizan, 1987 , Tafsir Al Misbah. Jakarta: Lentera Hati, 2009 Syafei, Akhmad, dkk. Pendidikan Agama Islam dalamPerspektif

Multikulturalisme. Jakarta: Balai Litbang Agama Jakarta, 2009

Syaibany, Omar Muhammad at Thoumy Al, Falsafah Pendidikan Islam. Jakarta: Bulan Bintang, 1979

Suriasumantri, Jujun S., Ilmu dalam Perspektif: Sebuah Kumpulan Karangan tentang Hakehat Ilmu. Jakarta: PT Gramedia, 1978

UU No 20 tahun 2004 tentang Sistem Pendidikan Nasional UU No 14 tahun 2005 tentang Guru dan Dosen

UU No 12 tahun 2012 tentang Perguruan Tinggi 
Program Studi Pendidikan Agama Islam Dalam Berbagai Sudut Pandang 